\title{
Mimari Restorasyon ve Konservasyon Projelerinde İşçi Sağlığı ve İş Güvenliği Uygulamaları
}

\author{
Mert UZUN ${ }^{1}$ \\ Deniz ÖZTÜRK ${ }^{2}$ \\ Gürkan Emre GÜRCANLI ${ }^{3}$
}

ÖZ

Tarihi eser ve dokuların özgün biçimleriyle korunarak, gelecek kuşaklara aktarılması restorasyon projelerinin nihai hedefidir. Restorasyon işlerinin kendine özgü yapısı, özel bir uzmanlık gerektirmekte ve bu projelere özgü riskler özgün işçi sağlığı ve iş güvenliği(İSİG) önlemlerini zorunlu kılmaktadır. Türkiye'de mevzuata göre mimari restorasyon faaliyetleri inşaat sektörünün bir parçası olarak ele alınsa da, restorasyon alanına özgü İSIGG önlemlerine dair çalışmalar yetersizdir. $\mathrm{Bu}$ çalışmada, mimari restorasyon faaliyetleri sırasında karşılaşılması olası riskler incelenmiş ve riskler mevzuat zorunlulukları ve saha gözlemlerine dayalı veriler ışığında fiziksel, kimyasal, biyolojik ve ergonomik tehlikeler bakımından sınıflandırılmıştır. Bu risklere ilişkin tartışmaların ardından, sağlıklı ve güvenli bir mimari restorasyon çalışması için risk değerlendirme rehberi ve akış şeması oluşturulmuştur.

Anahtar Kelimeler: İnşaat sektörü, mimari restorasyon, işçi sağlığı ve iş güvenliği, risk analizi.

\section{ABSTRACT \\ Occupational Health and Safety Practices in Architectural Restoration and Conservation Projects}

Preservation of historic buildings with their original state and conveyance that heritage to the next generations is the ultimate aim of the restoration projects. Restoration works requires special professional skills and the particular risks of these projects oblige peculiar occupational health and safety measures. Although, in Turkey, the architectural restoration works are regarded as a part of construction industry according to the legislation, research

\footnotetext{
Not: Bu yazı

- Yayın Kurulu'na 10 Temmuz 2019 günü ulaşmıştır. 16 Eylül 2019 günü yayımlanmak üzere kabul edilmiştir.

- 30 Kasım 2020 gününe kadar tartışmaya açıktır.

- https://dx.doi.org/10.18400/tekderg.590368

1 Yıldız Teknik Üniversitesi, Fen Bilimleri Enstitüsü, Endüstri Mühendisliği Ana Bilim Dalı, İstanbul mertuzunn@gmail.com - https://orcid.org/0000-0002-1494-2547

2 İstanbul Teknik Üniversitesi, Fen Bilimleri Enstitüsü, Restorasyon Programı, İstanbul deniz1612@gmail.com - https://orcid.org/0000-0002-8209-8157

3 İstanbul Teknik Üniversitesi, İnşaat Mühendisliği Bölümü, İstanbul - gurcanlig@itu.edu.tr https://orcid.org/0000-0002-0807-2020
} 
upon peculiar occupational health and safety measures are not sufficient. In this study, possible risks during architectural restoration projects were examined and those risks were classified as physical, chemical, biological and ergonomical risks according to legislative obligations as well as the data obtained from site observations. After the discussions upon these risks, a risk assessment guide and flowchart were established for healthy and safe restoration work.

Keywords: Construction industry, architectural restoration, occupational health and safety, risk analysis.

\section{GíRiş}

Koruma düşüncesi, tarihte çok gerilere götürülebilmektedir. 18. yy'da bazı yasal düzenlemelerle korumanın ilk adımları atılmaya başlanmasıyla birlikte, onarımların bilimsel yöntemle yapılan bir uğraş olarak ortaya konması 19.yy'da başlamıştır. Günümüze çok eski tarihlerden ulaşan, anıtsal ya da anıtsallıktan uzak, ait olduğu dönemin gündelik yaşamına dair fikir veren ve bugüne değer aktaran, teknolojik gelişmelerin aşamalarını günümüze taşıyan, bilgi aktaran, teknoloji tarihi açısından önem taşıyan yapılar korunmaya değer bulunmaktadır [1]. Bu geniş yelpazeden de anlaşılacağı gibi, neyin korunacağ koruma düşüncesi için temel sorulardan birisidir. 1976 yılında UNESCO tarafından kültürel geleneklerle ilgili maddi varlıkları da kapsamak üzere "kültürel varlık" tanımı ortaya konmuştur [2]. Ülkemizdeki koruma mevzuatı; değişik uygarlıkların sanat anlayışı, bilim ve teknik düzeyi, sosyal yaşamı hakkında somut veriler sağlayan ve korunmalarında kamu yararı görülen eşya ve yapıtları kapsamaktadır [3]. Burden, koruma düşüncesini "bir yapının bozulmasını, yıkılmasını, kötüye kullanımını veya bakımsızlığını önlemek üzere yapılan bakım ve müdahaleler" şeklinde tanımlamaktadır [4]. Bu tanımda "bakım" özellikle öne çıkarılmaktadır. Zakar, korumanın; "bir anıtı çevresiyle birlikte belgeleyerek, sürekli bakımını ve kullanımını sağlayarak, özgün durumunu muhafaza ederek, gerektiğinde en az müdahale ile onarma ve iyileştirme yollarına giderek varlığını sürdürme anlayışı” olduğunu söylemektedir [5]. Kültür ve Tabiat Varlıklarını Koruma Kanunu'nda koruma; taşınmaz ve tabiat varlıklarında muhafaza, bakım, onarım, restorasyon, fonksiyon değiştirme işlemleri olarak açıklanmaktadır [3]. Bu işlemlere tümleme, yenileme, yeniden yapım, taşıma, temizleme işlemleri de eklenebilir.

Restorasyon, koruma eyleminin en temel ve geniş kapsamlı bileşenlerinden birisidir. Hasar görmüş, özgünlüğünü yitirmiş, geleceğe sağlıklı ulaşamayacak yapı veya yapı grubunun elde edilen en güvenilir belge ve bilgi doğrultusunda, bilimsel teknik ve yöntemler eşliğinde, en az müdahale ile onarma ve yaşatma pratiğidir. Restorasyon faaliyetlerinin bahsedilen alt başlıklarının her biri özel uzmanlık gerektiren ve çoğu zaman disiplinlerarası çalışmayı zorunlu kılan faaliyetlerdir. Restorasyon çalışmalarına katılacak disiplinlerden biri de İSÍG olmalıdır. Restorasyon uygulamaları, bu alana özgün durumlarda çalışan uzman, tekniker ve işçiler bakımından birçok tehlike ve riski barındırmaktadır.

Restorasyon çalışmaları, ulusal mevzuatta yapı iş kolunun bir alt bileşeni olarak tarif edilmektedir [6]. Buna göre ülkemizde yapı iş kolunu ilgilendiren İSİG mevzuatı restorasyon projeleri için de geçerlidir. Yapı iş kolu, içerisinde birçok özel uzmanlık gerektiren ve alt başlığı bulunan geniş bir üretim yapısına sahiptir. Yapı iş kolunun bu özgün durumu, İSİG bakımından da her bir alt başlığın kendi özgün tehlike ve risklerine odaklanılmasını zorunlu 
kılmaktadır. Restorasyon faaliyetleri, geleneksel inşaat faaliyetlerinin tamamını bünyesinde barındırmakla birlikte, birçok inşaat projesinde karşılaşılması mümkün olmayan riskleri de aynı anda taşımaktadır. Çizelge 1'de geleneksel yapım faaliyetleri esnasında gerçekleşen iş kazalarının analizi gösterilmektedir. Çizelgedeki dikkat çekici husus, her farklı proje tipi için farklı kaza tiplerinin öne çıkmasıdır. Bu çizelgede yalnızca ölümle sonuçlanan kazalara yer verilmiş olup, yaralanmayla sonuçlanan kazaların büyük bir kısmının kayıt altına alınmamasından dolayı yaralanma verileri işlenmemiştir. Bu kaza tiplerinin birçoğu restorasyon faaliyetlerinde de geçerlidir; ancak çizelgede restorasyon faaliyetleri maalesef yer almamaktadır. Zira restorasyon uygulamalarındaki kazaların büyük bir kısmı çizelgedeki "Bina Projeleri" veya "Diğer" sütunu içinde yer almakta olup, verilerin kayıt altına alınmasındaki eksikliklerden dolayı net bir yorum yapılamamaktadır. Öte yandan, kendine has özellikler taşımakla birlikte, restorasyon uygulamalarını incelerken "Bina" ve "Diğer" tip şantiyelere odaklanmak bir başlangıç noktası olacaktır.

Çizelge 1 - İnşaat sektöründeki iş kazalarının şantiyelere göre dă̆llımı [7]

\begin{tabular}{|c|c|c|c|c|c|c|c|c|c|c|c|c|}
\hline $\begin{array}{l}\text { Kaza Tipi / } \\
\text { Şantiye Tipi }\end{array}$ & Bina & Yol & Demiryolu & Kanal & $\begin{array}{c}\text { Köprü } \\
\text { Viyadük }\end{array}$ & Tünel & $\underset{\text { Mendirek }}{\text { Liman }}$ & Baraj & Yıkım & $\begin{array}{l}\text { Enerji } \\
\text { Nakil }\end{array}$ & Diğer & Toplam \\
\hline İnsan Düşmesi & 880 & 8 & 1 & 19 & 15 & 0 & 2 & 13 & 8 & 22 & 60 & 1028 \\
\hline $\begin{array}{l}\text { Malzeme } \\
\text { Düşmesi }\end{array}$ & 150 & 15 & 4 & 11 & 3 & 15 & 3 & 22 & 4 & 6 & 18 & 251 \\
\hline $\begin{array}{l}\text { Malzeme } \\
\text { Sıçraması }\end{array}$ & 2 & 1 & 0 & 1 & 1 & 0 & 1 & 0 & 0 & 2 & 2 & 10 \\
\hline $\begin{array}{l}\text { Kazı Kenarı } \\
\text { Göçmesi }\end{array}$ & 60 & 4 & 0 & 68 & 1 & 1 & 3 & 0 & 1 & 0 & & 138 \\
\hline $\begin{array}{l}\text { Yapı Kısmının } \\
\text { Çökmesi }\end{array}$ & 105 & 1 & 0 & 2 & 4 & 0 & 0 & 1 & 41 & 0 & 13 & 167 \\
\hline $\begin{array}{l}\text { Elektrik } \\
\text { Çarpması } \\
\end{array}$ & 255 & 1 & 0 & 5 & 0 & 0 & 4 & 6 & 1 & 9 & 12 & 293 \\
\hline $\begin{array}{l}\text { Patlayıcı } \\
\text { Madde Kaza. }\end{array}$ & 4 & 24 & 0 & 8 & 0 & 5 & 0 & 3 & 0 & 1 & 5 & 50 \\
\hline $\begin{array}{l}\text { Y. Makinası } \\
\text { Kazaları }\end{array}$ & 33 & 90 & 0 & 13 & 4 & 2 & 6 & 19 & 1 & 7 & 31 & 206 \\
\hline $\begin{array}{l}\text { Uzuv } \\
\text { Kaptır./Sıkış. }\end{array}$ & 1 & 0 & 0 & 0 & 0 & 0 & 0 & 0 & 1 & 0 & 0 & 2 \\
\hline $\begin{array}{l}\text { Şantiye İçi } \\
\text { Trafik Kazası }\end{array}$ & 22 & 74 & 21 & 13 & 2 & 1 & 3 & 14 & 1 & 5 & 12 & 168 \\
\hline Diğer Tip & 23 & 9 & 0 & 7 & 6 & 0 & 2 & 7 & 0 & 6 & 25 & 85 \\
\hline Toplam & 1535 & 227 & 26 & 147 & 36 & 24 & 24 & 85 & 58 & 58 & 178 & 2398 \\
\hline
\end{tabular}

İnşaat faaliyetlerinin ve inşaatlarda gerçekleşen kazaların kayıt altına alınması için, her faaliyetin ilgili NACE (Nomenclature Générale des Activités Économiques dans les Communautés Européennes) kodlarına göre sınıflandırılması son derece önemlidir. İnşaat faaliyetleri 41 kodu ile başlayıp 43.99.15 NACE kodu ile biten ekonomik faaliyetleri kapsamaktadır. Restorasyon faaliyetleri "Mevcut ikamet amaçlı olan veya ikamet amaçlı 
olmayan binaların yeniden düzenlenmesi veya yenilenmesi (büyük çaplı revizyon)" (NACE Kodu 41.20.05) kapsamında değerlendirilebilir. Öte yandan "Özel İnşaat Faaliyetleri" (NACE kodu 43) ve onun alt başlığı olan "Başka Yerde Sınıflandırılmamış İnşaat Faaliyetleri” (NACE Kodu 43.99) sınıflandırmasına girip girmeyeceği tartışmalıdır. Zira bu ekonomik faaliyetin de alt sınıfları arasında yer alan "İnşaat iskelesi ve çalışma platformunu kurma ve sökme işleri”" (43.99.07), "Yapıların diş cepheleri için buharlı temizleme, kum püskürtme ve benzeri uzmanlaşmış inşaat faaliyetleri” (43.99.12) hemen hemen her türden restorasyon projesinde karşılaşılan faaliyetlerdir. Kendine özgü iş kalemleriyle geleneksel inşaat faaliyetlerinden farklılaşan ve kimi zaman sıradan bina inşaatları sınıflandırmasında değerlendirilen restorasyon faaliyetlerinin içerdiği farklı riskler ve bunları azaltma/yok etme yöntemleri bu çalışmanın kapsamını oluşturmaktadır. Bu makalede başlık olarak "mimari restorasyon" ifadesi kullanılmıştır. Zira bu çalışma, laboratuvarda ya da arkeolojik alanlarda yapılan restorasyon ve konservasyon uygulamalarındaki iş güvenliği ve işçi sağlığı uygulamalarını içermemektedir. Öte yandan, metni daha kolay okunur kılması bakımından, mimari restorasyon ve konservasyon çalışmalarını ifade etmek için metin içinde sadece "restorasyon" terimi kullanılmıştır.

\section{RESTORASYON PROJELERINE ÖZGÜ RİSK ETMENLERİ}

Genel olarak restorasyon işlerinde belli bir rutin oluşturmak son derece zor olup, her proje kendi özgünlüğü içerisinde ele alınmak zorundadır. Restorasyon işleri, yeni bir yapıyı inşa etmekten farklıdır ve en genel anlamıyla hali hazırda tümü ya da bir kısmı var olan bir tarihi yapıya, tüm hasar ve eldeki imkanlar değerlendirilerek koruma ve onarım anlamında en uygun müdahaleleri etmek demektir. Öte yandan müdahale edilen yapının eski olması, restorasyon işlerini Yapı İşlerinde İş Sağlığı ve Güvenliği Yönetmeliği'nde belirtilen "yenileme", "tadilat", "tamir" ve "montaj" işlerinden de ayırmaktadır. Dolayısıyla var olan yönetmeliklere uygun olmayan, modern yapım tekniklerinden farklı tekniklerin kullanıldığı, belirsizliklerin çok olduğu bu projelerde iş programı yapmak son derece güç olup, her tarihi yapıda konvansiyonel projelere göre göz önünde bulundurulması gereken çok daha fazla parametre bulunmaktadır. Genel olarak inşaatlarda alınacak önlemlerin yanı sıra, yapının inşa edildiği malzemenin çeşitliliği, ülkemizde çoğunlukla yığma olarak yapılan binaların malzemelerinin mekanik özelliklerinin tespitindeki zorluk ve belirsizlikler, bilgisayar ortamında kurgulanan yapısal modelleri her zaman sorgulanır kılmakta, yapının sorunlarının kesin biçimde bilinemezliği riskleri çeşitlendirmektedir [8].

Öte yandan restorasyon projelerinde "şantiye" tanımı ve sınırları oldukça belirsiz ve değişkendir. Genellikle trafiğin ve halkın yoğun olduğu, turizm faaliyetlerinin kümelendiği, dar sokak kurgusuna sahip tarihi kent dokusunun içindeki bölgelerde restorasyon uygulamalarının daha ağırlıklı gerçekleştiği söylenebilir. Bu etkenlere aşağıda ayrıntılı bir şekilde belirtilecek toz (ne tozu olduğunu saptamak bile zordur), kendi döneminde kullanılan ve değerli olan, ama günümüzde zararlı olduğu bilinen (Scheele Yeşili gibi) kimyasal boya ve malzemelerin varlığı, restorasyondaki yapıyı koruma ilkesi gereği yapı şartlarına uygun çalışma zorunluluğundan kaynaklı ergonomik risk etmenleri, yapıların içinde bulunan hayvan ölüleri (yarasa, fare gibi) ve ahşabı tahrip eden mantar ile böcek faaliyeti sonucu ortaya çıkan biyolojik riskler eklendiğinde, restorasyon uygulamalarındaki çalışma ortamının oldukça farklı olduğu görülmektedir. Restorasyon projeleri, yapı iş kolundaki birçok ana disiplini içerisinde barındırmasından kaynaklı olarak bu disiplinlerin kendine özgü tehlike ve 
risklerini de içermektedir. Yapı iş kolunda sıklıkla karşılaşılan iş kazalarındaki ana risk unsuru restorasyon faaliyetlerinde de geçerli olmakla birlikte restorasyon faaliyetlerinde riskin biçimi ve önem derecesi farklılık gösterebilmektedir. Restorasyon faaliyetleri iş kazalarının haricinde özellikle meslek hastalıklarına yakalanma riski bakımından da inşaat sektörünün diğer disiplinlerine göre oldukça fazla faktörü bünyesinde barındırmaktadır. Aşağıda temel risk etmenleri verilmektedir.

Yapıdaki hasar nedeniyle karşılaşılan riskler: Restorasyon projeleri çoğunlukla koruma altındaki yapıda herhangi bir hasar varsa, bu hasarın nedeninin belirlenip yapıya müdahale yöntemini belirlemeyi gerektirir. Yapılardaki hasarlar çoğu zaman zemin özellikleri, yanlış malzeme kullanımı, kötü işçilik, tasarım hatası, malzemenin doğal süreçler ile bozulması, afetler, savaşlar, yangınlar gibi sebeplerle ortaya çıkabilir. Yapıdaki hasarın risk olarak ortaya çıkması yapının henüz belgeleme aşamasında dahi ortaya çıkmaktadır. Bu nedenle hasarın tespiti ve hasara nasıl müdahale edileceği, belgeleme çalışması ile birlikte düşünülmelidir. Buradan hareketle yapıdaki hasarlara ilişkin gerekli önlemler alınmadan, belgeleme çalışması yapma amacıyla yapıda çalışmaya başlamanın bile başlı başına önemli bir risk olduğunu söylemek mümkündür. Bu nedenle, yapıdaki döşemelerin sağlamlığı, elektrik tesisatının güvenliği gibi fiziksel risk etmenlerine ek olarak yapı içerisinde zaman içerisinde oluşan bazı bitkiler (1sırgan otu ya da dikenli bitkiler gibi), kemirici hayvanlar, böcekler (akrep, pire gibi) gibi biyolojik risk etmenleri de tespit edilmelidir. Buradan hareketle restorasyonda İSIG yapı ya da yapı grubunun belgelenmesi aşamasından itibaren düşünülmesi gerektiğinin altı çizilmelidir. Restorasyonun uygulama aşamasında ise yapının statik kontrolü iş takviminde en öne konulması gereken başlıktır. Zira koruma altındaki binalarda taşıyıcı yapı elemanlarındaki yorulmalar ve hasarlar, yapının restorasyon faaliyetine alınmasının çoğu durumda gerekçesi durumundadır. Bu durum, yapının statik sorunlarının, aynı zamanda güçlendirme çalışmaları esnasında çalışanlar bakımından da ek riskler oluşturmasına neden olmaktadır. Yapının çoğu zaman güçlendirme çalışmalarının sürdüğü esnada diğer ince işçilikler de devam etmektedir. Bu durum ise birbirinden farklı risklere sahip aktivitelerin benzer alanlarda kesişmesine ve öngörülen risklerin farklılaşmasına neden olmaktadır.

Yüksekten düşme: Koruma altındaki yapıların büyük bir kısmı "bina” tipi yapılar olup, en fazla karşılaşılan iş kalemleri genellikle yüksekte çalışmaları içermektedir. Keza tarihi su kemerleri, surlar, köprüler, çeşitli anıtsal yapılarda da yüksekte çalışma önde gelen "tehlike" kaynağıdır. Yüksekte çalışmanın yarattığı yüksekten düşme riski, tıpkı diğer inşaat aktivitelerinde olduğu gibi restorasyon faaliyetlerinde de en önemli risktir. Restorasyon faaliyetlerinde bu riski arttıran unsur, yüksekte çalışma koşullarını zorlaştıran durumların varlığıdır. Yüksekte çalışma için kullanılacak erişim ekipmanlarının koruma altındaki yapıda güvenli bir şekilde konumlandırılması önemli bir sorundur. Örneğin yeni bir yapı inşasında iskele, yapının uygulanması sırasında süreç ile birlikte düşünülmekte ve tasarlanmaktadır. Restorasyon uygulamasında ise var olan ve hem güvenliğinden emin olunamayan hem de tarihi bir belge olarak korunması gereken yapı duvarları; iskelenin sabitlenmesine, buralara geçici ankraj ekipmanlarının yerleştirilmesine engel oluşturmaktadır. Benzer şekilde yatay ve düşey yaşam hatlarının yapı üzerine montajı da ek sorunlar yaratmaktadır. Restorasyon uygulamalarında yüksekte çalışma için alınacak önlemler ve çözümler her yapıya özgü olmak zorundadır. Çalışılan yapının bir kültür varlığı olduğu asla unutulmadan planlama yapılmalıdır. Restorasyon ve konservasyon çalışmaları yapılacak yapıların cephe tasarımları, inşa edildikleri dönemin mimari yaklaşımlarının izlerini üzerinde barındırmaktadır. Yeni 
dönemde daha fazla üzerinde durulan "tasarım yoluyla iş güvenliği”" yaklaşımından uzak olan bu yapıların cephelerinde (temizlik, plastik onarım vb.), çatılarında (kurşun yenileme vb.) yapılacak bazı işler için genellikle iskele kurulmakta ve yüksekte çalışma yapılmaktadır. İskele ile güvenli çalışma için belirlenmiş normlara göre iskelenin yapı ile arasındaki mesafesinin $30 \mathrm{~cm}$ olması tavsiye edilmektedir [9]. Ancak çoğu zaman standart tip iskeleler ile çalışmanın yapılacağı ve genellikle standart iskelelerin restorasyona konu olan yapıların cephelerinde gerekli esnekliği sağlayamamaları sebebiyle, tavsiye edilen mesafeyi yakalamak mümkün olmamaktadır. Bu durum, boşluksuz ve düşme tehlikesi barındırmaması gereken iskele çalışma alanında düşme riskini arttıran boşlukların oluşmasına neden olmaktadır. Bu nedenle özellikle iskele konusunda özel çözümleri düşünmek gereklidir. Benzer şekilde, iskelelerin yapı yüzeyinden ankre edilmesi(iskelenin yapı yüzeyine ankrajı) çoğu projede mümkün olamamaktadır. Bu durumda da her işe özel statik çözümler ile iskele kurulumunun gerçekleştirilmesi gerekmektedir. Ayrıca birçok projede uygulandığı üzere ahşap malzemelerden üretilen iskeleler, çelik alaşımlı iskele malzemelerinin zati yüklerinin fazla olması ve bu iskelelerin yapı geometrisine uygun monte edilememesi vb. nedenlerle tercih edilmektedir. Ne var ki uygulamalarda ahşap iskeleler ile ilgili EN 338 gereklilikleri karşılayan ahşap malzemeler ve yine EN 12811 iskele performans kriterlerini sağlayan kurulumlarının yaygın olmadığı belirtilmelidir.

Malzeme düşmesi: Eski eserdeki statik sorunlar yalnızca yüksekten düşme tipindeki kazaların oluşmasına değil aynı zamanda eserde bulunan bazı öğelerin (örneğin avize, tablo, duvar panosu vb.) bağlantı noktalarındaki zayıflamalar sonucu düşmesi ya da duvar vb. yapı elemanlarının devrilmesi ile çalışanların malzeme düşmesi sonucu kazaya maruz kalmasına neden olmaktadır. Ayrıca restorasyon çalışmaları esnasındaki artık malzemelerin binadan uzaklaştırması esnasında ve malzemelerin çalışma alanlarına ulaştırılması esnasında ek riskler mevcuttur. Projenin gerçekleştirileceği alanda yapılacak kaldırma operasyonlarının planlanması bu bakımından büyük önem taşımaktadır. Özellikle yapı meskun mahalde yer alıyorsa yapı çevresinde malzeme düşme riskine karşı özel önlemler (sınırlandırmalar, trafik ve yaya güvenliği) alınmalıdır.

Toz: Toza maruziyet, restorasyon uygulamalarında farklı yer ve yoğunlukta gerçekleşmektedir. Tozla Mücadele Yönetmeliği'nde belirtildiği üzere tozlu işlerde risk değerlendirmesi için toz ölçümleri yapılmalı ve sonuçları değerlendirilerek önlemleri alınmalıdır [10]. Uygulamalarda en yaygın kullanılan yapı malzemelerinden birisi doğal taştır. Geleneksel yapı malzemesi olması sebebiyle koruma çalışmalarında da benzer özellikteki malzeme kullanımı tercih edilmektedir. Kullanılan doğal taşlardan bazıları; Küfeki gibi kireç taşları, çeşitli mermer türleri ve bazalt gibi volkanik taşlardır. Taşların işlenmesi sırasında oluşacak taş tozu hem o taşı işleyen işçi, hem sahada çalışanlar, hem de önlem alınmadığı takdirde saha çevresindeki halk sağlığı açısından risk taşımaktadır. Bir diğer risk oluşturan restorasyon uygulaması ise özellikle cephe temizliğinde kullanılan kontrollü kumlamadır. Mikro kumlama olarak da anılan bu yöntem; özel aletlerle, basınçlı hava veya azot kullanılarak, yüzeydeki kir üzerine doğrudan metal esaslı, mikro cam küre, mineral esaslı (kum gibi), çeşitli organik (fındık kabuğu gibi)aşındırıcı malzemenin püskürtülmesi ile gerçekleştirilir. Dünyadaki en yaygın mineral olan ve kum, kumtaşı, granitte bulunan silika; özellikle kumlama işleminde kullanılmaktadır. Bu uygulama sırasında da önlem alınmadığı durumda basınçla püskürtülen organik veya inorganik malzeme soluma yoluyla risk oluşturmaktadır. Bu tozların solunduğunda birçok solunum yolu rahatsızlığına ve kansere neden olduğu bilinmektedir. Bunun için asbest" ve "eriyonit" 
gibi akciğer kanserine neden olan güçlü hastalık yapıcı tozların kullanılan malzemelerde olup olmadığını incelenmelidir. [11].

Özellikle Nevşehir taşının kullanımı ve pek çok taş iş̧̧iliği, toza maruziyet nedeniyle oluşabilecek hastalıkları tetiklemektedir. Bu hastalıkların genel adı pnömokonyozlar olup, kabul edilen son tanımlaması "akciğerlerde inorganik tozların birikmesi ve buna karşı gelişen doku reaksiyonudur" şeklindedir. [12]

Taş, kumlama gibi toza maruziyet oluşturabilecek alanlarda çalışanların koruyucu önlemleri alması, periyodik akciğer taramasından geçmeleri gerekmektedir. Ne yazık ki ülkemizde pek çok sektörde olduğu gibi, restorasyon çalışmalarında da meslek hastalıklarının kayıt altına alınması ve tanı konması neredeyse hiç gerçekleşmemektedir..Restorasyonun ele aldığ konusu gereği tarihi yapı ya da yerleşkede farklı dönemlerin teknolojileriyle üretilen, günümüzde özellikle sağlık sebebiyle kullanılmayan ya da tanınmayan malzemeler bulunabilir. Yine bu malzemeler de toza maruziyete önlem kapsamında uygulama öncesi malzeme analizi ile tespit edilmeli ve önlemi alınmalıdır.

Asbest: Restorasyon projelerinde karşılaşılabilecek önemli risklerin başında asbest maruziyeti gelmektedir. Asbestin üretimi, kullanımı ve asbest içeren eşyaların piyasaya sunulmasını "Bazı Tehlikeli Maddelerin, Müstahzarların ve Eşyaların Üretimine, Piyasaya Arzına ve Kullanımına İlişkin Kısıtlamalar Hakkında Yönetmelikte Değişiklik Yapılmasına Dair Yönetmelik" ile yasaklanmıştır [13]. Ancak eski yapılarda asbest varlığını sürdürmektedir ve asbestli alanlarda yapılacak yenileme çalışmaları esnasında asbest liflerinin solunması ciddi sağlık sorunlarına yol açmaktadır. Asbest $20 \mathrm{yy}$. ilk çeyreğinden sonra Dünya Sağlık Örgütü ve Uluslararası Kanser Araştırma Merkezi tarafindan "Kanserojen Maddeler" listesinde Grup 1A kanserojen madde olarak belirlenmiştir. "Mezotelyoma" veya "akciğer kanseri" can kaybına yol açarak, asbestin sebep olduğu en tehlikeli hastalık olarak bilinmektedir [14]. Kentsel dönüşüm sürecinde yıkılan binalarda olduğu gibi, restorasyon projelerinde de asbest ciddi sağlık risklerine yol açmakta olup, bu projelerde "Asbestle Çalışmalarda Sağlık ve Güvenlik Önlemleri Yönetmeliği" hükümlerine uygun çalışma yapılmalıdır [15]. Restorasyon projelerinde asbestli alanların kırılması/kazınması/yıkılması asbest liflerinin ortaya çıkmasına yol açtığından, bu projelere özgün bir risk faktörü olarak göz önünde bulundurulmalıdır.

Kurşun ve Kalay: Her iki madde de ağır metaller arasında yer almakta olup, her ikisi de biyobirikme eğilimli maddelerdir. Biyobirikim zamanla biyolojik bir organizmada bir kimyasal konsantrasyonun, kimyasalın doğadaki konsantrasyonuyla karşıllaştırıldığında artması demektir. Eski eserlerde sıklıkla kullanılan bir malzeme olan kurşun; kenet vb. metal bağlantılarda eritilerek, kaplama olarak kullanımında serilerek, dövülerek uygulanmaktadır. Restorasyon işlerinde çalışan işçiler, uzun yıllar boyunca özellikle kurşun ve kalay gibi ağır metallere maruziyet nedeniyle kurşun zehirlenmelerine ve uzun vadede ciddi hastalıklara yakalanma riski taşımaktadır [16]. Bu maddelere maruziyet yalnızca projelerde çalışan iş̧̧iler bakımından değil halk sağlığı bakımından da önemlidir. Zira 2019 yılında Paris’te bulunan Notre Dame Katedrali'nde çıkan yangın sonrasında, katedralin çatısında bulunan 300 tona yakın kurşun malzeme tamamen erimiş ve kurşun partikülleri havaya karışmıştır. Yangından iki ay sonra Paris merkezinde bir çocuğun kanında normal sınırların üzerinde kurşun tespit edilmesi üzerine ise halk sağlığı için özel önlemler alınması tavsiye edilmiştir [17]. 
Kimyasal maddeler: Restorasyon uygulamalarında kimyasal madde maruziyeti iki boyutlu olabilir: İlki yapıdan kaynaklı kimyasallara maruziyet, ikincisi ise uygulama sırasında kullanılan kimyasal malzemelere maruziyettir. Yapıdan kaynaklı kimyasallar; harcın, boyanın, malzeme üzerindeki bir konservasyon malzemesinin içeriğinde olabilir. Bu riski tespit etmek amacıyla işin başında malzeme analizi yapılması büyük önem arz etmektedir. Eski yapıdaki boyanın sökümü işi, uygulama sırasında işçi sağlığı açısından önlem alınması gereken iş kalemlerinden birisidir. Özellikle ahşap mimari elemanların üzerindeki yağlı boyaların sökümünde kullanılan tekniğe göre farklı kimyasallara maruziyet söz konusudur. Boya sökümü amacıyla raspa yapılıyorsa toza maruziyet, boya sökücüler kullanılıyorsa deriyle temasında ve sıcak hava tabancası ile uygulama yapılıyorsa soluma yoluyla kimyasala maruziyet gerçekleşebilir. Bunun haricinde restorasyon çalışmaları sırasında en fazla kimyasal malzeme kullanımı temizlik çalışmalarındadır. Standart bir inşaat faaliyetinden farklı olarak restorasyon faaliyetlerinde birbirinden farklı nitelikte ve riskte özel kimyasal temizleyiciler, yapıştırıcılar kullanılmaktadır. Taş temizliği çalışmalarında kullanılan kir absorblayıcı jeller (AB57 vb.), taş onarımında kullanılan epoksiler, metalraspa çalışmalarında (alem temizliği gibi) tercih edilen organik çözücüler bunlara örnek olarak verilebilir. Uygulanırken zararlı buharlar açığa çıkaran bu tür kimyasallara maruziyet bir diğer önemli risktir. Bu nedenle çalışmalarda kullanılacak kimyasal malzemelerin "Malzeme Güvenlik Bilgi Formları" mutlak suretle çalışma öncesinde incelenmeli, yapılacak risk değerlendirmesi neticesinde çalışanlar bilgilendirilerek gerekli önlemler alınmalıdır.

Yangın: Faaliyetler esnasında birçok fiziksel etmene (elektrik, sıcak çalışma vb.) bağlı olarak gelişebileceği gibi, çalışmanın yürütüldüğü eserin yapısı (ahşap olması vb.), projede kullanılan kimyasal malzemeler vb. birçok unsur yangın riskini arttırır. Restorasyon projeleri sıcak çalışmalar (kaynak, kesim vb.) aynı zamanda yanıcı malzemelerin bulunduğu alanlarda yapılmak zorunda olması nedeni ile yüksek yangın riski içermektedir. Bu binalardaki ahşap ve benzeri yanıcı malzemelerin -ki ahşap tozları son derece önemlidir- restorasyon işlerinin bir parçası olan yalıtım malzemeleriyle bir arada bulunması, kimi zaman bir el fenerinin veya kaynak makinasından gelecek kıvılcım ve alaz ile tutuşmaya yol açabilir. Yalıtım işlerinde kullanılan pürmüz gibi araçlar ise sıradan inşaata nazaran çok büyük risk unsurudur. Keza sigara içilmesinin kesinlikle önlenmesi önemlidir.

Bozunmuş organik bileşikler ve diğer biyolojik risk etmenleri: Eser bünyesinde bulunabilen hayvan dışkısı, yaşamını yitirmiş hayvanlardan kalan organik çözünmüş maddeler ve mikroorganizmalar çalışanlar için biyolojik riskleri de beraberinde getirmektedir. Özellikle ahşap binalarda döşeme ve kısıtlı alanlarda bu riskler mevcuttur. Ayrıca bazı bitkiler (1sırgan otu ya da dikenli bitkiler gibi), kemirici hayvanlar, böcekler (akrep, pire gibi) gibi biyolojik risk etmenleri tespit edilmeli ve çalışanları bu risklere karşı korumak için gerekli önlemler alınmalıdır.

\section{RESTORASYON PROJELERINDE SAĞLIK VE GÜVENLİK FAALİYETLERİ}

Restorasyon projelerinde etkin bir İSİG faaliyeti, bu faaliyetlerin yapı iş kolunda olduğu gibi projenin hazırlık aşamasından uygulama aşamasına uzanan evrelerinin tamamını kapsayacak şekilde kurgulanmalıdır. Faaliyetlere özgü riskler ve yapı iş kolunun diğer riskleri beraberce ele alınarak aşağıda belirtilen başlıklarda çalışmalar yapılmalıdır. Projenin hazırlık aşamasında proje risklerinin nasıl yönetileceğine ilişkin çalışmalar proje hazırlık ekibi 
tarafından gerçekleștirilmelidir. Bu kapsamda mevzuatta tanımlı görevlendirmeler (Proje Sorumlusu ve Sağllk ve Güvenlik Koordinatörü) gerçekleștirilmeli ve proje hazırlık faaliyetlerinde İSIG faaliyetleri planlanmalıdır. Projenin gerçekleştirileceği eserde ilk olarak ön risk analizi yapılmalı ve proje başlamadan alınması gereken önlemler belirlenmelidir. $\mathrm{Bu}$ başlıkta, projenin meskun mahalde olduğu hallerde kamu güvenliğinin sağlanması için oluşturulacak şantiye alanının sınırlarının belirlenmesi, şantiye giriş çıkış noktalarının tespiti, malzeme düşme riskine karşı alınacak tedbirler vb. önlemler planlanmalıdır. Binalarda taşıyıcı yapı elemanlarıyla birlikte yapısal olmayan malzemelere de yönelik kırılganlık analizlerinin yapılması gereklidir [18]. Yapılacak ön risk analizinde yapı stabilitesine dair gerekli numuneler alınarak yapıda öncelikle çalışanların güvenliğini sağlamak için güçlendirilmesi gereken alanlar tespit edilmelidir. Şekil 1'de bir güçlendirme örneği görülmektedir.

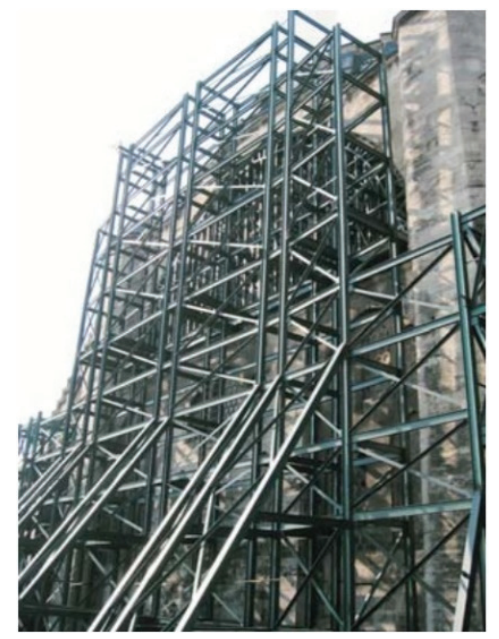

Şekil 1 - Mihrimah Sultan Camii mihrap cephesinde 1999 Kocaeli depremi sonrası kurulan çelik askı sistem ile güçlendirme çalışması [19].

Restorasyonu gerçekleştirilecek eserde asbest kullanılıp kullanılmadığı, asbest varsa kullanım alanların tespiti ve asbest içeren öğelerin sökümü için idari ve pratik faaliyetlerin nasıl yürütüleceği planlanmalıdır. Restorasyonu yapılan yapıda yüksekte ya da geniş açıklıkta yapılacak çalışmalar için uygun erişim ekipmanların malzeme seçimi, niteliğinin belirlenmesi (ahşap ya da ön yapımlı çelik bileşen), bağlantı noktalarının tespit edilerek iskele projelerinin hazırlanması gerekmektedir. Özelleşmiş iskele projeleri, mutlak suretle deneyimli mimar ve mühendislerce tasarlanmalıdır. Şekil 2'de bir restorasyon projesine özgü kurulmuş çelik konstrüksiyon ve iskele sistemi görülmektedir.

Tarihi yapılarda bulunan korkuluk veya merdiven korkulukları çoğunlukla yürürlükteki mevzuata uygun değildir. Bazen yapının özgün özelliklerini bozmadan bazı güvenlik önlemleri eklenebilir. Sürekli işçilerin inip çıktığı merdivenler, döşeme kenarları, balkonlar buna örnek verilebilir. Şekil 3'te Ottawa'da bulunan Ulusal Arşiv ve Kütüphane binası merdiven parmaklıklarının arasının basit bir uygulamayla sıklaştırıldığı ve yönetmeliğe uygun hale getirilerek düşmelere karşı önlem alındığı görülmektedir [21]. 

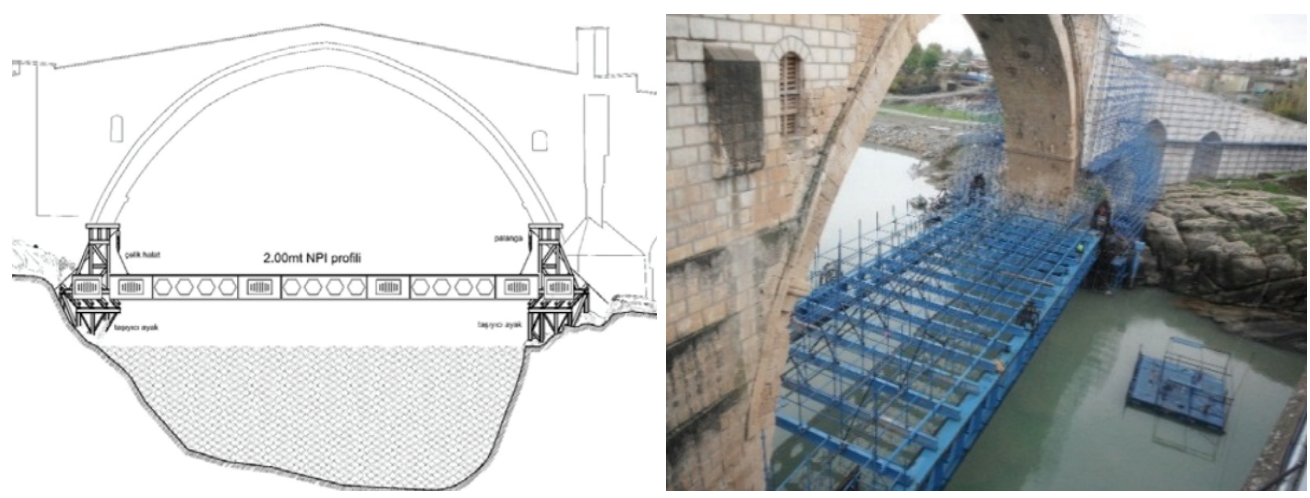

Şekil 2 - Malabadi Köprüsü restorasyonu sırasında kurulan iskele sistemi [20].

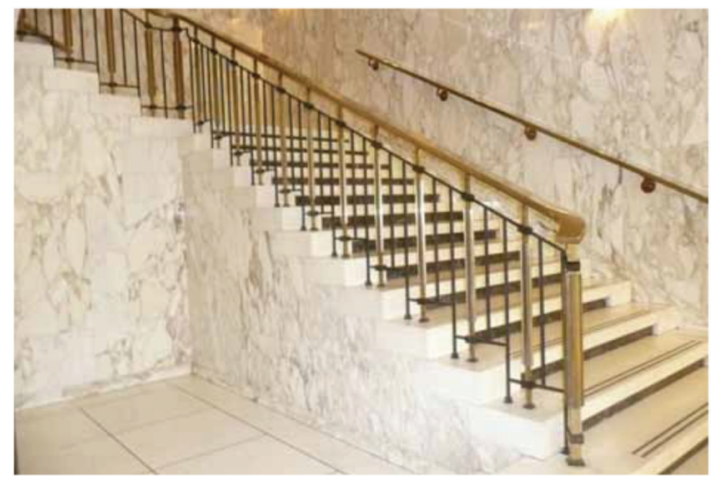

Şekil 3 - Tarihi bir yapıdaki merdiven korkuluklarının yürürlükteki mevzuata uygun hale getirilmesi.[21]

Faaliyetler boyunca yürütülecek aktivitelerin her biri için aktivite bazlı risk analizi çalışmaları yapılmalı ve aktivite bazlı güvenlik önlemleri tanımlanarak güvenli yapım yöntemleri oluşturulmalıdır. İş izni gerektiren çalışmalar (sıcak çalışma, kapalı alan çalışmaları vb.) bu analizlerin bir parçası olarak oluşturulmalıdır. Projedeki olası acil durumlara karşı analizler gerçekleştirilmeli ve projenin acil durum eylem planı henüz hazırlık aşamasındayken oluşturulmalıdır. Restorasyon faaliyetlerine özgü diğer risklere yönelik özellikli çalışmaların da analizi gerçekleştirildikten sonra yürütülecek diğer inşaat faaliyetleri için mevzuatta tanımlanan sağlı ve güvenlik planı hazırlanmalı, proje aşamasında yürütülecek tüm İSİG faaliyetleri bir sistematik içinde ele alınmalıdır.

Restorasyon uygulamalarında kimi zaman koruma uygulaması yapılan yapı ya da yapı grubu ziyaretçi kabul etmeye devam edebilir. Bu durumda restorasyon uygulamasındaki sağlık ve güvenlik önlemleri ziyaretçileri de kapsamalıdır. Şekil 4'te bir restorasyon projesinin devam ettiği esnada ziyaretçi kabulüne ilişkin güvenlik önlemleri (malzeme düşmesine engel olmak için ağ, örtü sitemleri, alan temizliği ve sınırlandırması vb.) görülebilmektedir. Sahaya girilmese bile şantiye sınırı tanımının oldukça değişkenlik göstermesi sebebiyle uygulama 
yapılan alanın özgün durumuna göre şantiye dışına dönük önlemler değerlendirilmelidir. Örneğin, tarihi yarımadada (İstanbul) bulunan dar bir sokaktaki bir çeşmenin restorasyon çalışmaları planlanırken yoğun turizm işlevi ve ulaşılabilirlik alınacak önlemler ve zaman planlaması bakımından hesaba katılmalıdır. Projede yüklenici seçimi, süre planlaması, malzeme seçimi vb. diğer idari ve pratik faaliyetler ele alınırken gerçekleştirilen bu analizlerden faydalanılmalı ve daima risk kontrol hiyerarşisi uyarınca çalışmalar sürdürülmelidir.

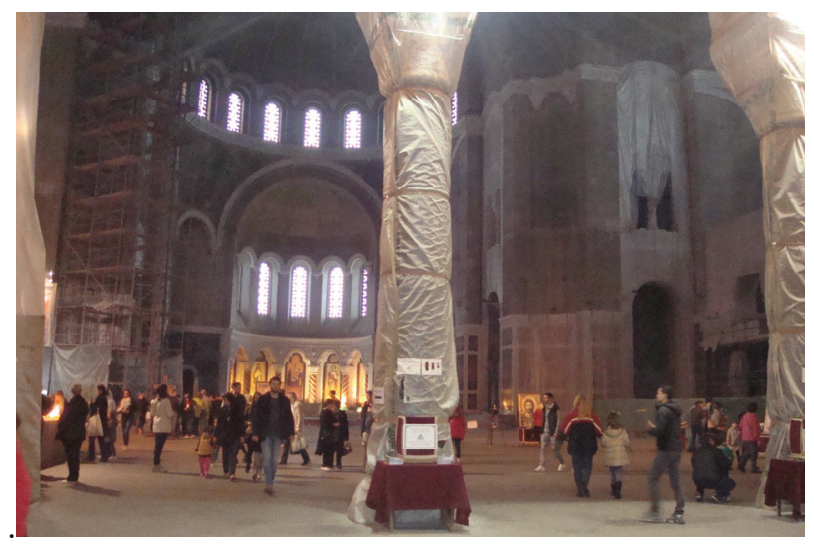

Şekil 4 - Belgrad'taki Aziz Sava Katedrali'nin restorasyon uygulaması sırasında ziyaretçi kabulü

Aşağıda yer alan tabloda restorasyon projelerinde İSİG önlemleri bakımından önemli risklerin klasik inşaat projelerinden farkları belirtilmiştir.

Projenin uygulama aşamasında, hazırlık aşamasında oluşturulan sağlık ve güvenlik planı çerçevesinde faaliyetlere başlanmalıdır. Bu çerçevede, yapı işine ilişkin idari bildirimler, uygulama aşaması için yapılması gereken görevlendirmeler projenin ilk adımı olarak gerçekleştirilmelidir. Restorasyon projesi için oluşturulacak şantiye düzeni daha önce yapılmış planlamalara göre sağlanmalıdır. Çalışmaların yapılacağı eserde ilk çalışmalar, ön risk analizi sonucunda ortaya çıkan, çalışanların ve kamu güvenliğinin sağlanmasına yönelik çalışmalar olmalıdır. Projenin güvenli bir çalışma ortamını sağladığından emin olunduktan sonra ise daha önce proje için hazırlanan sağlık ve güvenlik planının işletilmesine geçilmelidir.

Ayrıca yine ulusal mevzuata göre projenin tamamlanmasının ardından, işletme sürecinde ya da bakım/onarım işlerinde çalışacakların sağlık ve güvenlik ile ilgili dikkat etmesi gereken hususlarla ilgili sağlık ve güvenlik dosyası hazırlanmalıdır. Bu dosyada, proje ile ilgili teknik bilgilere yer verilmeli ve işletme safhasında projenin yapımından kaynaklanan riskler ortaya çıkmışsa gerekli uyarılar yapılmalı, alınan güvenlik önlemleri var ise bunlar tariflenmelidir. Bunun için binanın mevcut fonksiyonu ve iyileştirme çalışması yapıldıktan sonraki (restorasyon sonrası) fonksiyonu tanımlanmalıdır. Örneğin tescilli kültürel varlık niteliğinde olan bir banka binasının, restorasyon sonrası müze fonksiyonuna dönmesi sürecinde, binanın işletim aşamasındaki sağlık ve güvenlik parametreleri göz önüne alınmalıdır. 


\section{Çizelge 2 - Restorasyon projelerine özgü İSiG önlemleri}

\begin{tabular}{|c|c|c|}
\hline No & Uygulama & İşçi Sağlığı ve İş Güvenliği Uygulamasına İlişkin Faaliyetler \\
\hline 1 & İskele Kurulumu & $\begin{array}{l}\text { Standart yönetmeliğe tabi olmakla birlikte, yapıya zarar vermeme ilkesi gereği her } \\
\text { zaman iskele yapıya sabitlenemeyebilir. Bu karar işi yaptıran idarenin kontrol } \\
\text { teşkilatının izni ve yapının statik anlamda güvenirliğinin tespiti sonrasında verilebilir. } \\
\text { Ayrıca yapının kütlesel özellikleri (kubbe, tonoz, yivli duvarlar gibi) de iskele } \\
\text { kurulumunu ve yapıya yaklaşmayı zorlaştıran etmenlerdir. Bu nedenle ahşap iskele } \\
\text { kurulması durumu oluşursa EN normlarına uygun ahşap iskele projesinin } \\
\text { hazırlanmasına özen gösterilmelidir. }\end{array}$ \\
\hline 2 & \begin{tabular}{|l|} 
Bina İçinde \\
Boşlukları Kapatma
\end{tabular} & $\begin{array}{l}\text { Yapıya zarar vermeme ilkesi gözetilerek yerine getirilmelidir. Bunun için zemine } \\
\text { kapama malzemelerinin çakılması çoğu zaman mümkün olmamaktadır. }\end{array}$ \\
\hline 3 & $\begin{array}{l}\text { Korkuluk } \\
\text { Yerleştirme }\end{array}$ & $\begin{array}{l}\text { Yapıya zarar vermeme ilkesi gereği yerine getirilerek uygulanmalıdır. Büyük oranda } \\
\text { yere ankre edilebilen geçici kenar koruma sistemleri yerine denge ağırlıklarına sahip } \\
\text { EN } 13374 \text { standartlarına uygun kenar koruma sistemleri tercih edilmelidir. }\end{array}$ \\
\hline 4 & $\begin{array}{l}\text { Girgır Vinç/Yük } \\
\text { Asansörü }\end{array}$ & $\begin{array}{l}\text { Yapıya zarar vermeme ilkesi yerine getirilmeli ve gerekli durumda da yapının statik } \\
\text { anlamda güvenirliği tespit edilmelidir. }\end{array}$ \\
\hline 5 & Ahşap İskele & $\begin{array}{l}\text { Yapıda iskele projelendirmesinde gözetilecek hususlardandır. İskele zati yüklerinin } \\
\text { yapıya zarar verme potansiyeli taşıdığı yerlerde hafif bir malzeme olması nedeniyle } \\
\text { tercih edilebilir. İskele Tebliği uyarınca } 13,5 \text { metreye kadar olan yüksekliklerde ahşap } \\
\text { iskelede C16 mukavemetine sahip ve standartlara uygun ahşaplardan imal edilmiş } \\
\text { iskele kullanılmalıdır. }\end{array}$ \\
\hline 6 & $\begin{array}{l}\text { Güvenlik Ağ1 } \\
\text { Yerleştirme }\end{array}$ & $\begin{array}{l}\text { Güvenlik ağı ankraj noktalarının stabilite analizi yapılmaksızın ve yapıyı koruma ilkesi } \\
\text { gözetmeksizin kullanımı mümkün olmayabilir. Bu durumda toplu koruma önlemi } \\
\text { olarak hava yastıklarından faydalanılabilir. }\end{array}$ \\
\hline 7 & $\begin{array}{l}\text { Yaşam Hatları } \\
\text { Kurulumu }\end{array}$ & $\begin{array}{l}\text { Yaşam hatlarının ankraj noktaları için yapıyı koruma ilkesi gereğince uygun dayanıma } \\
\text { sahip bağlantı noktaları belirlenmelidir. Ankraj noktaları için özel projelendirme } \\
\text { yapılmalıdır. Ankraj yapmanın mümkün olmadığı durumlarda denge ayaklarına sahip } \\
\text { EN normalarına uygun mobil yaşam hatları tercih edilmelidir. }\end{array}$ \\
\hline 8 & $\begin{array}{l}\text { Yangına Karşı } \\
\text { Koruma }\end{array}$ & $\begin{array}{l}\text { Yapı içerisinde sıcak çalışma (kaynak, kesim vb.) yapılması durumunda yapıyı koruma } \\
\text { ilkesi gereği iş izin sistemi kurulmalıdır. Kaynak battaniyesi vb. özel önlemler sıcak } \\
\text { çalışmaların olduğu alanlarda uygulanmalıdır. }\end{array}$ \\
\hline 9 & Elektrik Tesisatı & $\begin{array}{l}\text { Yapının elektrik tesisatının çoğu durumda eskimiş olacağı gözetilerek şantiye } \\
\text { kurulumundan önce elektrik tesisatı ile ilgili uygunsuzluklar tespit edilmelidir. Yangın } \\
\text { riskini önemli ölçüde arttıran elektrik uygunsuzlukları giderilmeden çalışmalara } \\
\text { başlanmamalıdır. }\end{array}$ \\
\hline 10 & $\begin{array}{l}\text { Malzeme Düşmes } \\
\text { Karşı Önlem }\end{array}$ & $\begin{array}{l}\text { Koruma altına alınacak yapıların çoğunun meskun mahalde olması ihtimaline karşı, } \\
\text { proje başlangıcında öncelikli olarak çevre güvenliği projelendirilmelidir. Ayrıca } \\
\text { restorasyonu yapılan yapının bazı kısımlarının yerinden kopması, kırılması, devrilmesi } \\
\text { gibi inşaatlarda pek rastlanmayan durumlara ilişkin de önlemler (güvenlik ağları, alan } \\
\text { sınırlandırmalar vb.) alınmalıdır. }\end{array}$ \\
\hline 11 & $\begin{array}{l}\text { Kaldırma } \\
\text { Operasyonları }\end{array}$ & $\begin{array}{l}\text { Yapı üzerine kurulacak makara, caraskal vb. kullanarak yapılan kaldırma operasyonları } \\
\text { için yapı dayanımına uygunluğun gözetilmesi gerekmektedir. Mutlak suretle bu } \\
\text { operasyonlar için kaldırma planı hazırlanmalıdır. }\end{array}$ \\
\hline 12 & Eğitim & $\begin{array}{l}\text { Restorasyon projelerinde çalışacak işçilerin "Restorasyon Elemanı" mesleki eğitimi } \\
\text { almış çalışanlar olmasına dikkat edilmelidir. Ayrıca işçiler projeye özgü İSİG riskleri } \\
\text { ve alınan önlemler konusunda ayrıca bilgilendirilmelidir. }\end{array}$ \\
\hline 13 & $\begin{array}{l}\text { Sağlık Risklerine } \\
\text { Karşı Önlemler }\end{array}$ & $\begin{array}{l}\text { Yapıda asbest, kurşun, kalay gibi zararlı malzemelerin varlığı saptanmalıdır. } \\
\text { İş kalemleri arasında toz çıkaracak iş kalemleri varsa, toz ölçümü yapılmalı gerekli } \\
\text { önlemler alınmalıdır. Biyolojik riskler önceden saptanmalı, kişisel koruyucu, aşı, } \\
\text { ilaçlama gibi önlemler alınmalıdır. Restorasyon işine özgü sağlık riskleri konusunda } \\
\text { çalışanlar bilgilendirilmelidir. }\end{array}$ \\
\hline
\end{tabular}




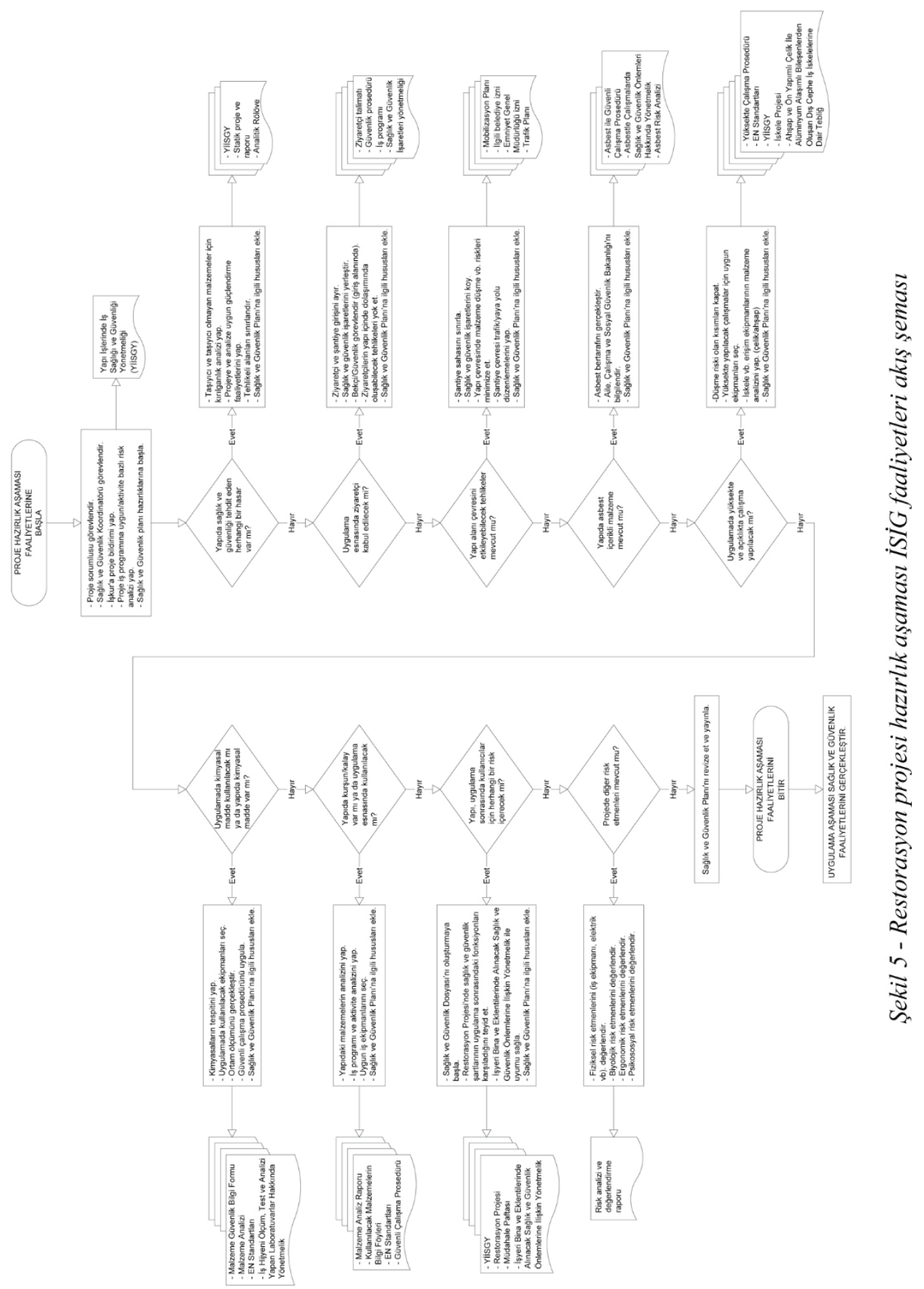


Güvenli bir restorasyon projesi gerçekleştirmek için projenin hazırlık aşamasında atılması gereken adımlar çalışmanın ekinde verilen Şekil 5'te akış şeması olarak tariflenmiştir. Bu şemada yer verilen hususlar yalnızca projenin hazırlık aşamasında bazı özel risklere odaklanmış olup projenin uygulama aşamasında uygulanacak diğer İSİG çalışmalarının detaylarını içermemektedir. Unutulmamalıdır ki eksiksiz bir İİG faaliyeti, projenin tamamlanmasının ardından, işletmesi safhasında risklerin minimize edilerek teslim yapılmasıdır. Bunun için de inşaat projelerinde bu kapsamı karşılayacak İSİG yönetim sisteminin kurulması önem arz etmektedir [22].

\section{SONUÇ}

Restorasyon faaliyetleri, her ne kadar yapı iş kolunun genel özelliklerini içerisinde barındırsa da kendine özgü riskleri bulunan özellikli faaliyetlerdir. Bu çalışmada, restorasyon faaliyetlerinin bu özel durumu ele alınmış ve yürütülecek faaliyetler esnasında dikkat edilmesi gereken ana unsurlara değinilmiştir. Herhangi bir inşaat projesinde olduğu gibi, restorasyon projelerinde de hazırlık aşaması son derece önemli olup, inşaat proje yönetiminin temel başlıkları arasında yer alan İSİG yönetimi açısından, inşaat öncesi evrede yapılacaklar önem kazanmaktadır. Restorasyon projelerine başlamadan önce diğer inşaat projelerinde de yapılması zorunlu olan risk değerlendirmesi, iş güvenliği analizi, alınması gereken önlemlerin belirlenmesi, hazırlanması gereken belgelerin düzenlenmesi gibi birçok başlık bir yönetim sistemi çerçevesinde ele alınmalıdır. [23] Başarılı bir İSG performansı için inşaat faaliyetlerine özgün bir İSG yönetim sistemi tayin edilmelidir. [24] Bu çalışmada restorasyon çalışmalarına özelleşen tehlike ve risklere dikkat çekilmiş, yapım faaliyetleri ile restorasyon faaliyetleri arasındaki farklara vurgu yapılmış ve kolay uygulanabilir bir yol haritası önerilmiştir. Bu ekin restorasyon faaliyetlerinde çalışan/çalışacak mühendis, mimar ve diğer teknik elemanlara bir rehber olacağ 1 düşünülmektedir.

\section{Kaynaklar}

[1] Ahunbay, Z., Tarihi Çevre Koruma ve Restorasyon, Yap1 Yayın, İstanbul, 2004.

[2] UNESCO, Kültür Varlıklarının Uluslararası Mübadelesine İlişkin Tavsiye Kararı, Nairobi, 1976

[3] 2863 sayılı Kültür ve Tabiat Varlıklarını Koruma Kanunu, 23 Temmuz 1983, T.C. Resmi Gazete, sayı 18113

[4] Burden, E.E., Illustrated Dictionary of Architectural Preservation: Restoration, Renovation, Rehabiltation, Rese, McGraw-Hill, 2004.

[5] Zakar,L., Eyüpgiller, K.K., Mimari Restorasyon Koruma Teknik ve Yöntemleri, İstanbul, 2015.

[6] Yapı İşlerinde İş Sağlığı ve Güvenliği Yönetmeliği, 05/10/2013 tarihli ve 28786 sayılı Resmi Gazete http://www.resmigazete.gov.tr/eskiler/2013/10/20131005-2.htm, Erişim Tarihi: 30.03.2019. 
[7] Gürcanlı G.E., İnşaat Şantiyelerinde Bulanık Kümeler Yardımıyla İş Güvenliği Risk Analizi Yöntemi, Yayınlanmamış Doktora Tezi, İstanbul Teknik Üniversitesi Fen Bilimleri Enstitüsü, 2006.

[8] Kocaman, İ., Okuyucu, D., Kazaz, İ., Tarihi Yapı Malzeme Özelliklerinin Dinamik Parametrelerle Belirlenmesi: Lala Paşa Camii Örneği, Teknik Dergi, 30 (3), 9125-9146, 2019.

[9] DIN EN 12811 Standard1

[10] Tozla Mücadele Yönetmeliği, 05/11/2013 tarihli ve 28812 sayılı Resmi Gazete http://www.resmigazete.gov.tr/eskiler/2013/11/20131105-9.htm, Erişim Tarihi: 08.07.2019.

[11] Atabey, Eşref. (2009). Türkiye'de Asbest, Eriyonit, Kuvars ve Diğer Mineral Tozları ve Etkileri, Maden Tetkik ve Arama Genel Müdürlüğü

[12] Türk Toraks Derneği, Akciğerde Toz Birikmesi: Pnömokonyoz, https://www.toraks.org.tr/news.aspx?detail=2578, Erişim tarihi:06.09.2019

[13] Bazı Tehlikeli Maddelerin, Müstahzarların ve Eşyaların Üretimine, Piyasaya Arzına ve Kullanımına İlişkin Kısıtlamalar Hakkında Yönetmelikte Değişiklik Yapılmasına Dair Yönetmelik, 21/11/2014 tarihli ve 29182 sayılı Resmi Gazete http://www.resmigazete.gov.tr/eskiler/2014/11/20141121-6.htm, Erişim Tarihi: 08.07.2019

[14] Akboğa, Ö., Baradan, S., Asbestin İnşaat Sektöründeki Yeri ve Maruziyetin Önlenmesi, Türkiye Mühendislik Haberleri, 469-6/2011-5

[15] Asbestle Çalışmalarda Sağlık ve Güvenlik Önlemleri Yönetmeliği, 25/01/2013 tarihli ve $28539 \quad$ sayılı Resmi $\quad$ Gazete http://www.resmigazete.gov.tr/eskiler/2013/01/20130125-24.htm, Erişim Tarihi: 08.07.2019

[16] Özbolat, G., \& Tuli, A., Ağır Metal Toksisitesinin İnsan Sağlığına Etkileri, Arşiv Kaynak Tarama Dergisi, 25(4), 502-521, 2016.

[17] https://www.livescience.com/65451-notre-dame-sky-high-lead-levels.html, Erişim Tarihi: 08.07.2019

[18] Kuzucuoğlu, A.H, Karatepe, Y., Tümer, E., Koruma Altındaki Binalarda SağlıkGüvenlik Parametreleri Açısından Tehlike Etmenleri, Uluslararası Hakemli Beşeri ve Akademik Bilimler Dergisi, Ekim/Kasım/Aralık-Sonbahar Dönemi, 4, 14, 2015.

[19] Sesigür, H., Çelik, O.C., Çı1ı, F., Tarihi Yapılarda Taşıyıcı Bileşenler, Hasar Biçimleri, Onarım ve Güçlendirme, İMO İstanbul Bülten, 89, 10-21, 2007.

[20] Halifeoğlu, F.M, Noyan, C., Halifeoğlu, Z., Tarihi Malabadi Köprüsü’nün Restorasyon Çalışmasında Kullanılan İskele Sisteminin Özellikleri ve Korumadaki Önemi, Uluslararası Katılımlı 6. Tarihi Yapıların Korunması ve Güçlendirilmesi Sempozyumu, 579-587, Trabzon, 2017.

[21] Provincial, A. F., \& Collaboration, T., Standards and Guidelines for the Conservation of Historic Places in Canada, 2014. 
[22] Uzun M., Gurcanli G.E., Change in Occupational Health and Safety Management System: ISO 45001, 5th International Project and Construction Management Conference, IPCMC2 018,16-18 November 2018

[23] Yilmaz F, Alp S., (2016)Underlying Factors of Occupational Accidents: The Case of Turkey, Open Journal of Safety Science and Technology, 2016, 6, 1-10

[24] Uzun M., Gürcanlı G.E, (2016)İnşaatlarda İşçi Sağlığı ve Güvenliği Yönetimi, Türkiye Mühendislik Haberleri Dergisi, TMH 489-2016/1, Page No: 20-27 